\title{
Studies of the vegetation \\ of a white-sand black-water igapó (Rio Negro, Brazil)
}

Shirley H. Kuo Keel (*)

Ghillean T. Prance (")

\section{INTRODUCTION}

Since Takeuchi's preliminary investigation (1962), there have not been any detailed studies dealing with the vegetation structure of central amazonian igapós. The forests studied by Black et al. (1950) near Rio Guamá and by Pires and Prance (1977) in the Catú Reserve (both in the vicinity of Belém), though termed igapós, are in fact white-water várzea forests. Similarly, in his paper on igapó forests along the Rio Negro and its tributaries, Takeuchi treated the mixed water várzeas of Lago Janauacá as igapós. To a great extent, this confusion is the resuit of inconsistent use of terminology for amázonian vegetation types subject to inundation. The correct application of terms to amazonian forest types subjected to inundation was fully discussed by Prance (1979). He suggested that the term "igapó" be restricted to forests inunciated by black or clear waters. In the present study, Prance's definition of igapó will be used.

The seasonal igapós in the Amazon basin are flooded annually by the rise of water level of black water rivers. In the case of the Rio Negro, flooding is during the rainy season from December to May (Table 1 \& Fig. 1); the water level does not recede until well into August, which is the midale of the dry season (Fig. 2). Although temperature is uniformly high throughout the Amazon basin, soil shows great variety and thereby plays a more important role than climate in the differentiation of vegetation types (Ducke \& Black, 1953). Igapó vegetation growing on different soil types exhibits different physiognomies. Some seasonal igapós occur on white-sand podzol and are flooded annually by black water, which ranges in $\mathrm{pH}$ from 3.7 to 5.4 (Sioli, 1958). The investigation of amazonian podzol has revealed that it is extremely deficient in nutrients. Rich in white quartz, this soil is highly porous and therefore rapidly leached by the usual heavy tropical rain. Its acidity results in low ion-retention capacity (Klinge, 1965; Stark, 1971; Stark \& Jordan, 1978). The poverty of this soil and seasonal flooding act as important edaphic factors which determine the vegetation of igapós. The purpose of this study was to investigate the effect of this environmental stress on the igapó vegetation, and especially to determine the relationship between stress and dominance.

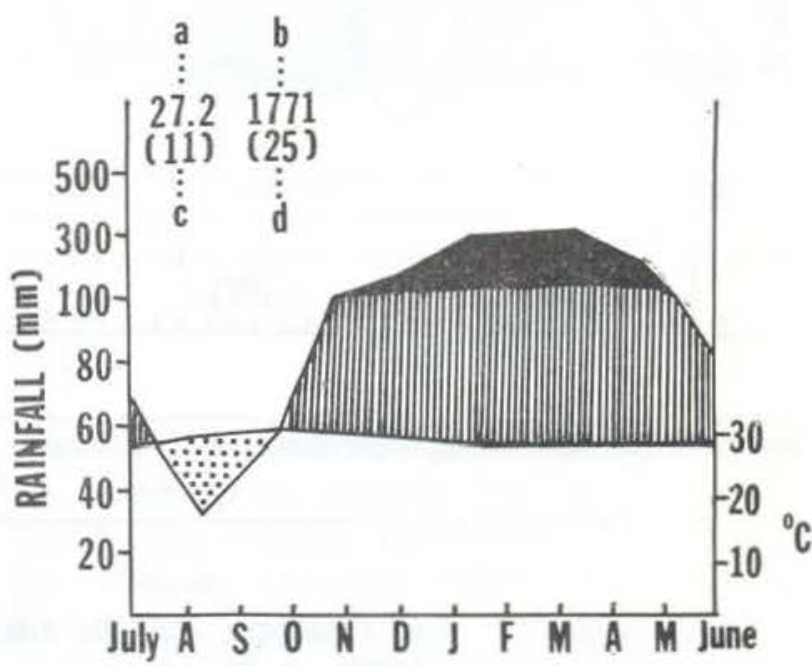

Fig. 1 - Climate diagram for Manaus (adapted from Climate-diagram map of South America. Walter et al. 1975). a: mean annual temperature $\left({ }^{\circ} \mathrm{C}\right)$; b: mean annual precipitation $(\mathrm{mm}) ; \mathrm{c}$ : number of years with records of temperature; $d$ : number of years with records of precipitation; dotted area represents dry season; area with vertical hatching represents relatively humid season; shaded area represents monthly precipitation in excess of $100 \mathrm{~mm}$ (note the scale is reduced to $1: 10$ so that one scale interval represents $200 \mathrm{~mm}$ ).

(") - The New York Botanical Garden, Bronx New York 10458 
The study area, a white-sand, black-water igapó, is located on the north bank of the Rio Negro near Manaus $\left(3^{\circ} 2 ' S, 60^{\circ} 8^{\prime} \mathrm{W}\right)$, about $1 \mathrm{~km} \mathrm{E}$ of the confluence of Igarapé Tarumä and the Rio Negro. The area is relatively undisturbed and has a uniform topography with a gentle slope (a vertical change of $5 \mathrm{~m}$ in about $50 \mathrm{~m}$ horizontal or $10 \%$ slope). During the rainy season, the extent of flooding determines the duration and depth of inundation along the slope. In the present study, the flood level along this slope is treated as a moisture gradient.

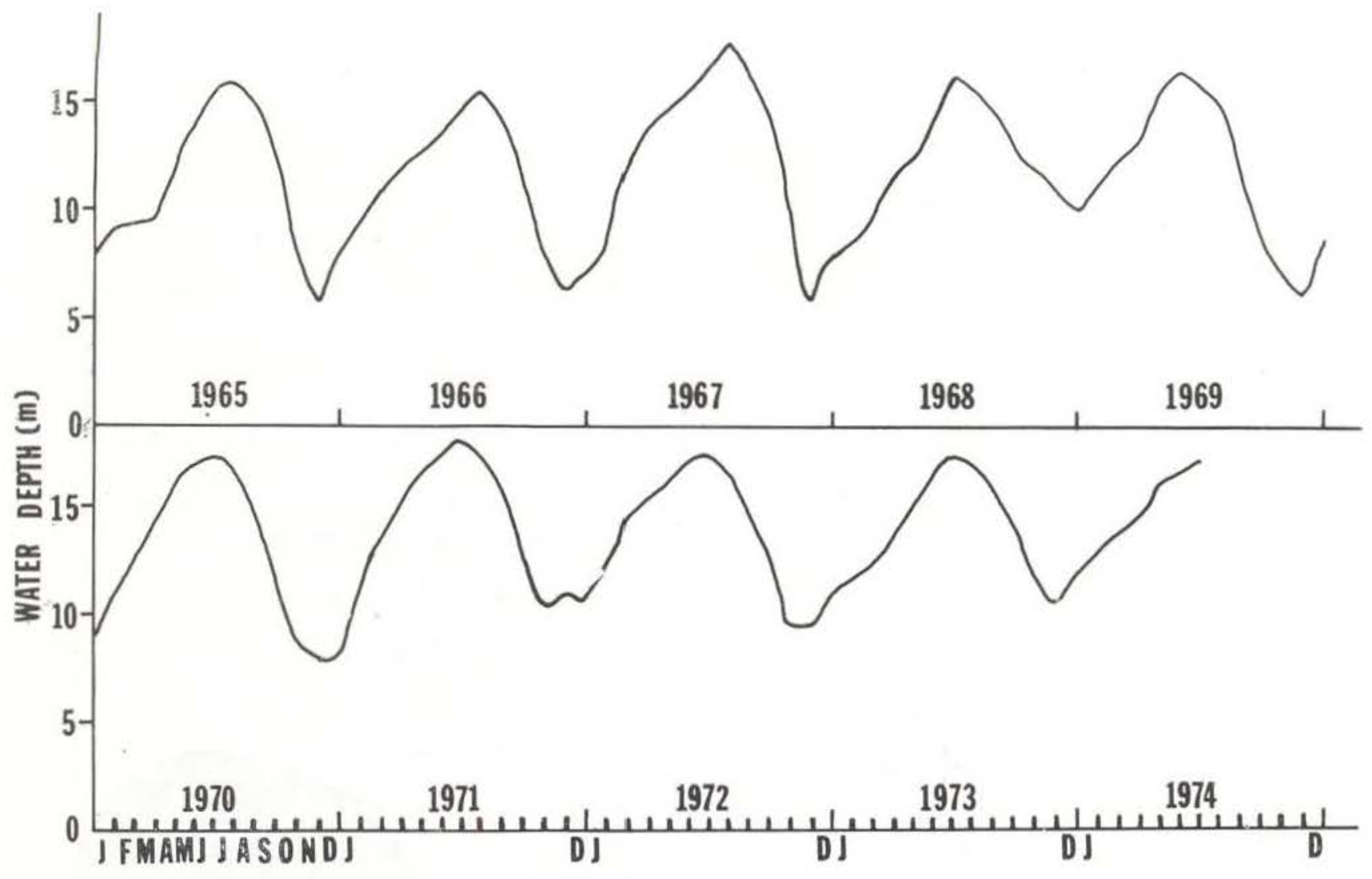

Fig. 2 - The variation of water depth of the Rio Negro at Manaus over a ten-year period (from Prance \& Arias, 1975. Fig. 3).

TABLE 1. Climatic data of Manaus (Wernstedt, 1972)

\begin{tabular}{|c|c|c|c|c|c|c|c|c|c|c|c|c|c|c|c|c|c|}
\hline $\begin{array}{l}\text { BRAZIL } \\
\text { STATION }\end{array}$ & YRS & ELEV & LAT & LONG & JAN & FEB & MAR & APR & MAY & JUNE & JULY & AUG & SEPT & OCT & NOV & DEC & ANNUAL \\
\hline \multirow[t]{2}{*}{ Manaus } & 30 & 157 & $3.08 \mathrm{~S}$ & $60.01 \mathrm{~W}$ & 10.87 & 10.91 & 11.85 & 11.30 & 7.60 & 3.90 & 2.40 & 1.61 & 2.44 & 4.41 & 6.50 & 8.98 & 82.72 \\
\hline & & & & & 79.5 & 78,6 & 79.0 & 79.3 & 80.2 & 79.7 & 79.2 & 80.2 & 80.4 & 81.0 & 80.8 & 81.0 & 79.7 \\
\hline
\end{tabular}

"YR" (Year) represents the number of years of record over which the monthly and annual precipitation values have been computed. "ELEV" (Elevation) represents the elevation in feet above mean sea level of the reporting station.

"LAT" (Latitude) and "LONG" (Longitude) represent latitudes and longitudes to the nearest degree and minute. "E" (East) or "W" (West) indicate longitudes east or west of the Greenwich Meridian,

The first (or upper) line of data given for each station represents the monthly and annual precipitation in inches and hundredths. The second (or lower) line of data given for each station represents the average monthly and annual temperatures in degrees and tenths Fahrenheit. 


\section{MÁTERIALS AND METHODS}

The field work was carried out in 1977 from October to December. During the dry season, the limit of the igapó can be easily recognized by the attachment of sponges (Photo 1) and flood marks on stems of trees and shrubs. A preliminary study was made to determine an adequate sample area. Figure 3 indicates that numbers of species increase sharply with the initial increase of area. However, the increase levels off after a sample of $1,800 \mathrm{~m}^{2}$, with 68 species inciuding vines and herbs (54 species excluding vines and herbs).

The igapó vegetation was sampled by means of 12 randomly chosen plots, each 10 $x 15$ meters. These plots were laid with their longer sides at a right angle to the shore. Within each plot, trees and shrubs higher than $1 \mathrm{~m}$ were recorded and their diameters at ground level were measured. The importance

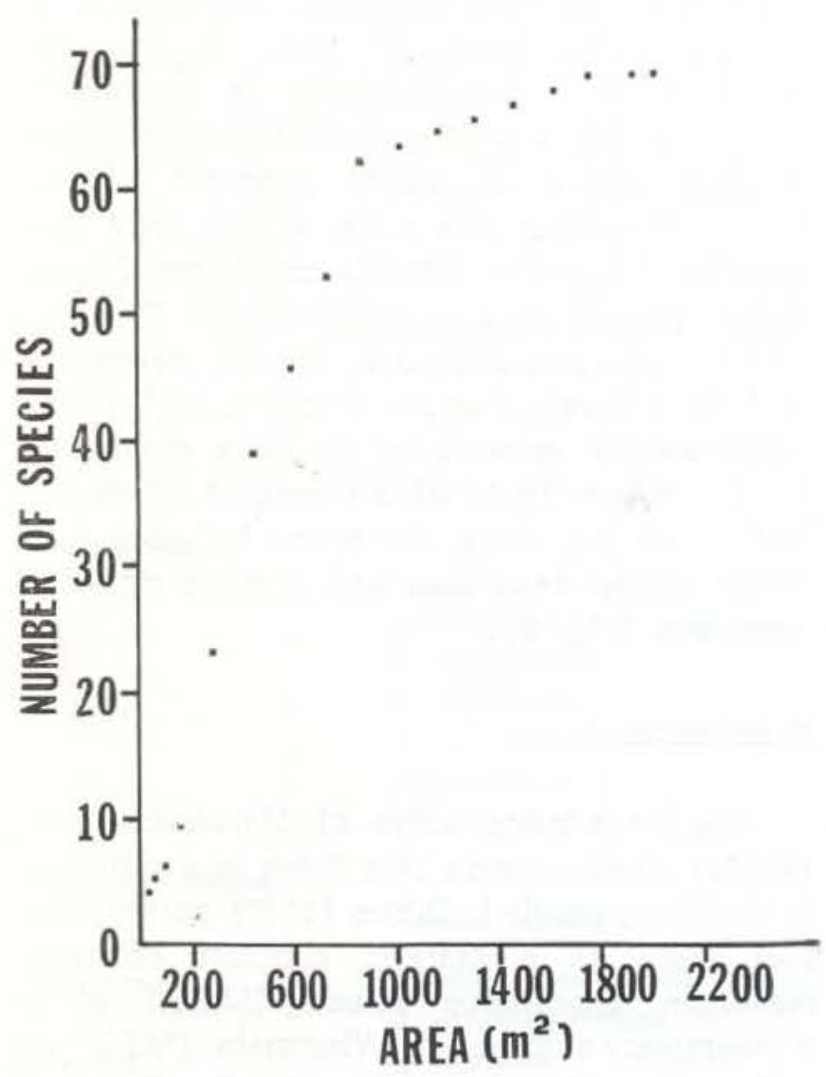

Fig. $3-$ Species-area curve for 14 plots of $150 \mathrm{~m}^{2}$ area. The graph shows the cumulative number of species in relation to the increase in numbers of plots sampled.

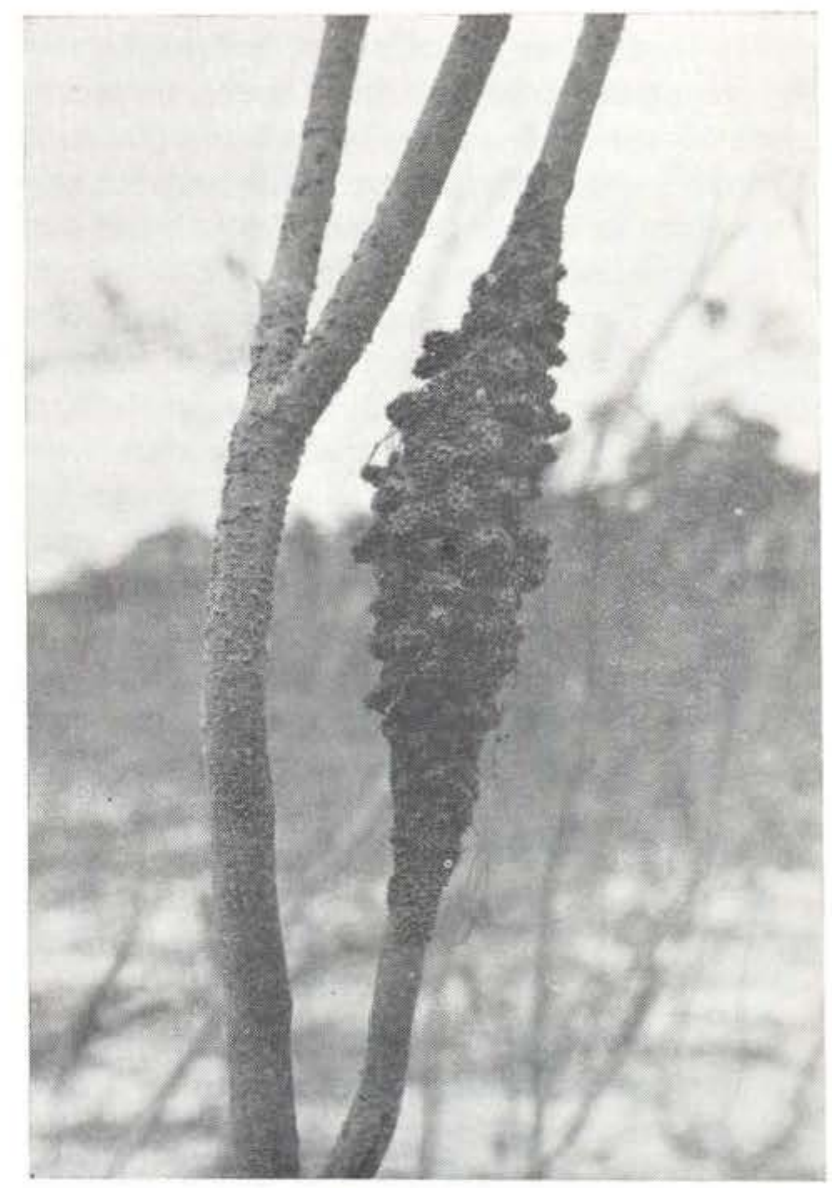

Photo 1 - Sponge attached on the branch of a shrub. This is used as a demarcation of inundated area. The highest point of sponge attachment is used to estimate the flood level at a given area.

value (I.V.) for each species was calculated by summing up relative frequency, relative density and relative dominance. To calculate the Shannon diversity index $(\mathrm{H})$ and the evenness index (e) the following formula was used (Odum, 1971):

$$
\begin{aligned}
\overline{\mathrm{H}}=-\sum \mathrm{P}_{\mathrm{i}} \log \mathrm{P}_{\mathrm{i}}\left(\mathrm{P}_{\mathrm{i}}=\right. & \text { importance probabili- } \\
& \text { ty for each species } \\
= & \text { importance value for } \\
& \text { each species }
\end{aligned}
$$

total of importance values)

$$
e=\frac{\bar{H}}{\log _{2} S} \quad \text { (S: number of species) }
$$


To investigate the effect of moisture stress on vegetation change, five linear transects, each $50 \mathrm{~m}$ long and $50 \mathrm{~m}$ apart, were placed at a right angle to the shore. One transect was only $40 \mathrm{~m}$ in length because of an abrupt $1 \mathrm{~m}$ rise above which terra firme vegetation was present. Trees and shrubs higher than $1 \mathrm{~m}$ and within $50 \mathrm{~cm}$ on both sides of transect lines were recorded, and their diameters at ground level were measured. The data from each $10 \mathrm{~m}$ segment of 5 transects were pooled separately, and the importance values were determined. The flood levels at each $10 \mathrm{~m}$ interval of transects were obtained by the highest points of sponge attachment on stems. Vouchers of sterile plant specimens from transects and plots were deposited in INPA, while those of fertile plants were deposited in INPA (Ist set) and NY (3rd set).

\section{RESULtS}

The study site is a low, open to closed one-story forest consisting of shrubs $2-5 \mathrm{~m}$ high as the main life-form. The leading dominant in the area is Myrciaria dubia with an I.V. 75.78 (Table 2). The subdominant species are Pithecellobium adiantifolium (I. V. = 33.74), Eugenia cachoeirensis (I. V. $=30.96$ ), and $E$. chrysobalanoides (I. V. $=19.41$ ). The Shannon diversity index $(H), 4.358$ bits per individual, is based on samples of 12 plots which contain 54 species of trees and shrubs higher than $1 \mathrm{~m}$ with 1028 individuals. This value represents an estimate; the total number of species in the community studied is actually unknown. For this reason, 4.358 bits per individual is a slightly underestimated value (Pielou, 1975). The evenness value of abundance $75.73 \%$ indicates that most species have few individuals.

Transect data (Table 3) suggest that species with I.V. $\geqq 50$ change nearly every $10 \mathrm{~m}$, an arbitrarily dividing unit for segments of transects. The same leading dominant, Myrciaria dubia occurs in both the $0-10 \mathrm{~m}$ and the $10-20 \mathrm{~m}$ segments, though the species composition of these two segments is very different. Myrciaria dubia has a higher I.V. in the $0-10 \mathrm{~m}$ segment than in the $10-20 \mathrm{~m}$ segment, where the dominance is shared by Pithecellobium adiantifolium. Within the $20-30 \mathrm{~m}$ segment, Schistostemon macrophyllum and Eugenia chrysobalanoides are the dominant species with I.V. $\geqq 50$. The high I.V. of S. macrophyllum, a tree, is derived largely from high relative domirance, whereas the high I. V. of E. chrysobalanoides, a shrub, is largely the result of high relative density. Eugenia cachoeirensis assumes the dominance in the $30-40 \mathrm{~m}$ segment, whereas Pera distichophylla and E. cf. patrisii are the dominant species in the $40-50 \mathrm{~m}$ segment.

Although species zonation is obvious, along the moisture gradient boundaries of the zones are not abrupt (Fig. 4). Myrciaria dubia occurs only in the segments close to the water (between $0-30 \mathrm{~m}$ ), and its abundance decreases along each subsequent $10 \mathrm{~m}$ segment. Eugenia cachoeirensis and E. chrysobalanoides grow between the area delimited by the second and fourth segment, while Schistostemon macrophyllum can be found only up to the third segment. Although $E$. cf. patrisii grows from the third to the fifth segment, Pera distichophylla is limited to segments four and five. Pithecellobium adiantifolium grows in every segment of the transects except the first, where only four species (M. dubia, Remijia tenuiflora, Tococa subciliata and Turnera acuta) occur. The area covered by the first and second segments, with flood levels that are 4 to $6 \mathrm{~m}$ high in the rainy season, appears to be more open with the individual plants widely spaced (Photo 2). Further up the slope, the space between individual plants decreases and species richness increases (Fig. 5).

\section{Drscussion}

The importance value of Myrciaria dubia (75.78) demonstrates that there is dominance in the igapó studied. Dittus (1977) pointed out that there is a marked contrast between maximum importance values (M.I.V.) of a temperatezone forest in Wisconsin (M.I.V. = 228) and equatorial rainforests in Brazil and in Borneo (M.I.V. $=23.42 \& 14$ ). The M.I.V. of igapó vegetation is notably higher than those of rainforests which do not have clear-cut 
TABLE 2. Data of vegetation analysis from 12 plots

\begin{tabular}{|c|c|c|c|c|c|}
\hline Family & Species & $\begin{array}{l}\text { Relative } \\
\text { Frequency }\end{array}$ & $\begin{array}{r}\text { Relative } \\
\text { Density }\end{array}$ & $\begin{array}{l}\text { Relative } \\
\text { Dominance }\end{array}$ & $\begin{array}{l}\text { Importance } \\
\text { Value }\end{array}$ \\
\hline Annonaceae & Duguetia uniflora & 0.662 & 0.098 & 0.337 & i. 097 \\
\hline \multirow[t]{4}{*}{ Apocynaceae } & Anacampta rupicola & 2.649 & 1.944 & 0.480 & 5.073 \\
\hline & Himatanthus attenuatus & 3.974 & 1.453 & 0.900 & 6.327 \\
\hline & Apocynaceae I & 0.662 & 0.098 & 0.005 & 0.765 \\
\hline & Apocynaceae II & 0.662 & 0.098 & 0.005 & 0.765 \\
\hline \multirow[t]{2}{*}{ Arecaceae } & Bactris sp. & 0.662 & 0.193 & 0.0097 & 0.865 \\
\hline & Leopoldinia pulchra & 5.298 & 5.550 & 5.937 & 16.785 \\
\hline \multicolumn{6}{|l|}{ Chrysobalanaceae } \\
\hline & $\begin{array}{l}\text { Couepia paraensis ssp. } \\
\text { paraensis }\end{array}$ & 1.325 & 0.298 & 0.058 & 1.681 \\
\hline & Licania apetala & 1.325 & 0.196 & 0.126 & 1.647 \\
\hline \multicolumn{6}{|l|}{ Euphorbiaceae } \\
\hline & Hevea sp. & 1.987 & 0.385 & 0.136 & 2.508 \\
\hline & Mabea occidentalis & 0.662 & 0.298 & 0.058 & 1.018 \\
\hline & Pera distichophylla & 0.662 & 0.098 & 0.337 & 1.097 \\
\hline & Euphorbiaceae i & 0.662 & 0.098 & 0.005 & 0.765 \\
\hline \multicolumn{6}{|l|}{ Flacourtiaceae } \\
\hline & Casearia cf. commersoniana & 1.325 & 0.875 & 0.108 & 2.308 \\
\hline Humiriaceae & Schistostemon macrophyllum & 1.987 & 0.298 & 1.378 & 3.663 \\
\hline \multicolumn{6}{|l|}{ Leguminosae } \\
\hline \multirow[t]{3}{*}{ Fabaceae } & Dalbergia inunciata & 1.325 & 2.521 & 1.431 & 5.277 \\
\hline & Dipteryx cf. oppositifolia & 1.325 & 0.193 & 1.724 & 3.242 \\
\hline & Sweetia nitens & 1.987 & 0.298 & 0.036 & 2.321 \\
\hline \multicolumn{6}{|l|}{ Caesalpiniaceae } \\
\hline & Campsiandra comosa & 4.636 & 1.068 & 4.075 & 9.779 \\
\hline & $\begin{array}{l}\text { Hymenaea courbaril } \\
\text { var. subsessilis }\end{array}$ & 0.662 & 0.098 & 0.862 & 1.622 \\
\hline & Macrolobium multijugum & 0.662 & 0.193 & 0.0097 & 0.865 \\
\hline & Peltogyne venosa & 0.662 & 0.193 & 0.031 & 0.886 \\
\hline \multicolumn{6}{|l|}{ Mimosaceae } \\
\hline & Parkia auriculata & 0.662 & 0.098 & 0.862 & 1.622 \\
\hline & Pithecellobium adiantifolium & 6.623 & 15.181 & 11.931 & $33.735^{*}$ \\
\hline & P. amplissimum & 0.662 & 0.098 & 0.005 & 0.765 \\
\hline & P. claviflorum & 0.662 & 0.098 & 0.005 & 0.765 \\
\hline & P. cf. glomeratum & 1.325 & 0.193 & 0.031 & 1.549 \\
\hline & Leguminosae I & 0.662 & 0.098 & 0.005 & 0.765 \\
\hline & Leguminosae II & 0.662 & 0.098 & 0.005 & 0.765 \\
\hline \multicolumn{6}{|l|}{ Melastomataceae } \\
\hline & Tococa subciliata & 1.325 & 0.193 & 0.031 & 1.549 \\
\hline \multirow[t]{7}{*}{ Myrtaceae } & Eugenia cachoeirensis & 7.948 & 6.899 & 14.563 & $30.959^{*}$ \\
\hline & E. chrysobalanoides & 5.961 & 8.562 & 4.883 & $19.406^{\circ}$ \\
\hline & E. inundata & 0.662 & 0.098 & 0.026 & 0.786 \\
\hline & E. longiracemosa & 1.987 & 9.140 & 1.228 & 12.355 \\
\hline & E. cf. patrisii & 1.987 & 0.770 & 1.055 & 3.812 \\
\hline & E. cf. teffensis & 0.662 & 0.098 & 0.121 & 0.881 \\
\hline & Eugenia $\mathrm{sp}$ & 1.987 & 0.683 & 0.331 & 3.001 \\
\hline
\end{tabular}


TABLE 2 (continued)

\begin{tabular}{|c|c|c|c|c|c|}
\hline Family & Species & $\begin{array}{l}\text { Relative } \\
\text { Frequency }\end{array}$ & $\begin{array}{l}\text { Relative } \\
\text { Density }\end{array}$ & $\begin{array}{l}\text { Relative } \\
\text { Dominance }\end{array}$ & $\begin{array}{c}\text { Importance } \\
\text { Value }\end{array}$ \\
\hline & Myrcia sp. & 0.662 & 0.098 & 0.026 & 0.786 \\
\hline & Myrciaria dubia & 7.948 & 30.449 & 37.38 & $75.777^{\circ} \bullet$ \\
\hline & Myrciaria sp. & 0.662 & 0.193 & 0.0097 & 0.865 \\
\hline \multirow[t]{2}{*}{ Polygonaceae } & Coccoioba excelsa & 0.662 & 0.098 & 0.026 & 0.786 \\
\hline & Ruprechtia tenuiflora & 1.987 & 1.261 & 3.186 & 6.434 \\
\hline Proteaceae & Roupala obtusa & 0.662 & 0.298 & 3.035 & 3.995 \\
\hline Rubiaceae & Remijia tenuiflora & 1.325 & 0.298 & 0.174 & 1.797 \\
\hline \multirow[t]{4}{*}{ Sapotaceae } & Franchetella crassifolia & 1.325 & 0.193 & 1.483 & 3.001 \\
\hline & Manilkara amazonica & 1.325 & 0.098 & 0.820 & 2.243 \\
\hline & Sapotaceae 1 & 0.662 & 0.193 & 0.242 & 1.097 \\
\hline & Sapotaceae II & 0.662 & 0.098 & 0.005 & 0.765 \\
\hline \multirow[t]{3}{*}{ Simaroubaceae } & Simaroubaceae I & 0.662 & 0.098 & 0.121 & 0.881 \\
\hline & Simaroubaceae II & 0.662 & 0.098 & 0.005 & 0.765 \\
\hline & Simaroubaceae III & 0.662 & 0.098 & 0.005 & 0.765 \\
\hline Solanaceae & Solanum sp. & 2.649 & 0.771 & 0.039 & 3,459 \\
\hline \multicolumn{6}{|l|}{ Sterculiaceae } \\
\hline & Buettneria obliqua & 0.662 & 0.098 & 0.005 & 0.765 \\
\hline Turneraceae & Turnera acuta & 7.286 & 5.831 & 0.313 & 13.43 \\
\hline
\end{tabular}

Shannon Diversity Index: $\overline{\mathrm{H}}$ (bits per individual) $=4.358$

Evenness Index: $\mathrm{e}=\frac{\overline{\mathrm{H}}}{\log _{2} \mathrm{~S}}=75.73 \%$ (S: number of species $=54$ )

* leading dominant

- subdominants

dominant species. However, the dominant and subdominant species in this study site, Myrciaria dubia, Pithecellobium adiantifolium, Eugenia cachoeirensis, and E. chrysobalanoides, do not necessariiy characterize all white-sand igapós along the Rio Negro. The forest inventories throughout Amazonia have revealed that characteristic species of forests differ from area to area within a short distance. Thus, to define the forest by characteristic species is often misleading (Pires \& Prance, 1977).

The change of species distribution occurs along transects. About $10 \mathrm{~m}$ from the shore, the area is overwhelmingly dominated by Myr. ciaria dubia. Beyond $10 \mathrm{~m}$, Pithecellobium adiantifolium, Schistost Eugenia chrysobalanoides, E. cachoeirensis and Pera distichophylla appear and increase in their relative importance sequentially. The rapid change of dominant species within a short distance in a homogeneous substrate (white-sand) points to the influence of other important environmental factors, e.g. flood level. The physiological basis of flood tolerance has been discussed by Crawford (1976) . McMannon \& Crawford (1971) demonstrated that in anaerobic conditions flood-intolerant species accumulate ethanol, whereas floodtolerant species undergo a metabolic change, accumulating malate rather then ethanol. To overcome the lack of $\mathrm{O}_{2}$, flood tolerant species use more effectively nitrate as an alternate electron acceptor (Garcia-Noro et al., 1973) Since the area has a gentle $10 \%$ slope, vegetation near the shore is water-logged longer and deeper than that in the upper area. Thus 
the change of species along the moisture gradient probably reflects the difference of physiological ability to flood tolerance.

The transects cover unly sandy areas exposed in the dry season. There are permanent water-logged areas with sparse vegetation stretching out from the shore into the water (Photo 3). Due to limited time avallable for field work, they were not subjected to the transect analysis. Eugenia inundata, Sphinctanthus striiflorus and Securidaca longifolia are most frequent in the water. Takeuchi (1962) indicated that $E$. inundata is a dominant

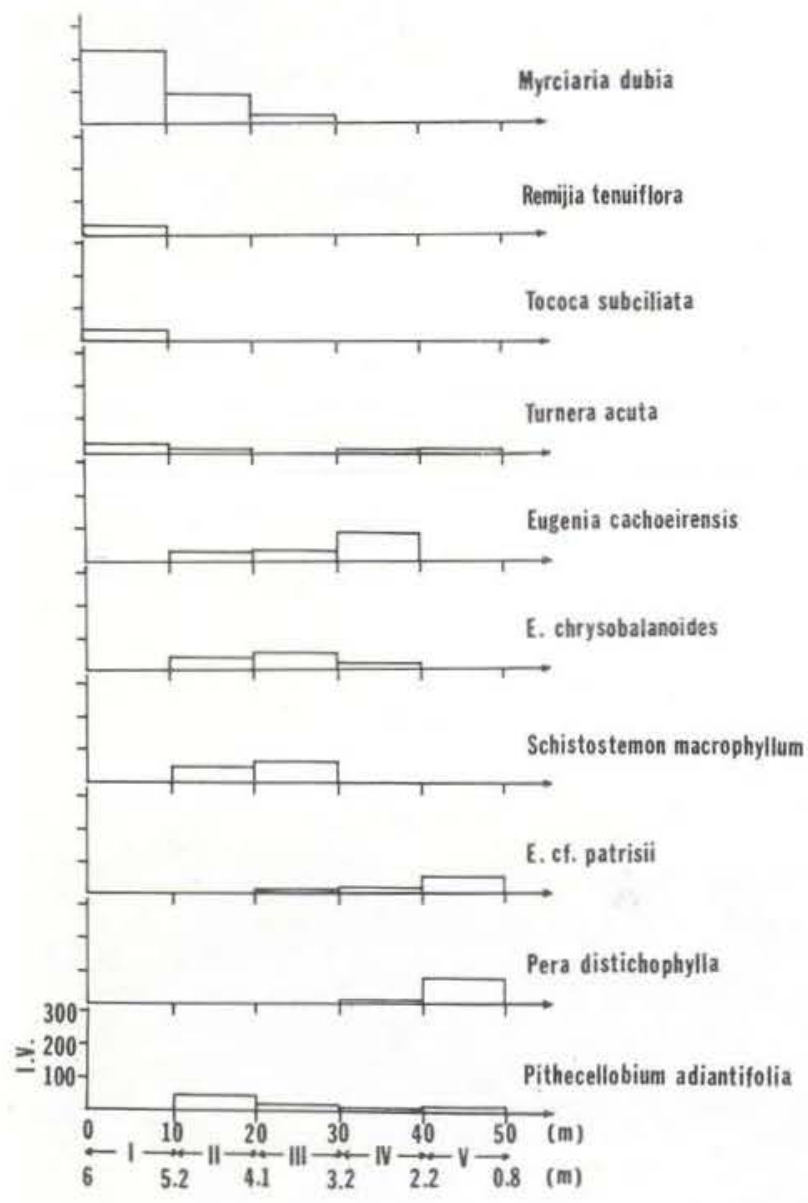

Fig. 4 - Schematic diagram of change in species distribution along the transects. Ordinate: Importance Value. Abscissa: upper Arabic Numerals represent distance from the shoreline; middle Roman Numerals represent segments of transect; lower Arabic Numerals represent estimated flood level at each $10 \mathrm{~m}$ transect segment. The flood level along a $10 \%$ slope is here used as a moisture gradient. See text for the explanation of change in species distribution. of igapó forests along river shores and permanentily inundated islands. However, according to the authors' observation, this species is mainly restricted to the permanent waterlogged area regardless of whether the water is of black or white type. Along sandy beaches which become dry annually for a period of time, different dominant species, such as Myrciaria dubia, occur.

The various adaptive strategies of igapó vegetation to seasonal inundation and drought merit further investigation. The study a a woody swamp in Suriname has shown that some trees survived during high water periods by becoming partly deciduous in the crowns or by corky breathing roots (pneumatophores) which bend down sometimes during low water period and develop as prop roots. Others, felled by the flood, regenerate vegetatively with root suckers (Teunissen, 1976). In the area studied, pneumatophores are seen on the trunk of an unknown tree. The vegetation change during the rainy season remains to be investigated. Prance (1979) indicated that some igapó vegetation displays xeromorphic adaptation to seasonal ciryness with sclerophyllous leaves. Since no plant with sclerophyllous leaves or other morphological adaptation was noted, the drought effect on vegetation in this igapó may not be very severe. However, the studies of sap tension of flooded trees and shrubs along the Rio Negro near Manaus showed that many plants such as Ruprechtia sp., Parkia auriculata, Eugenia sp., etc. reached zero turgor without wilting at the peak of hot days (Scholander \& Perez, 1968). It may well be possible that this physiological property contributes to the tolerance to drought during the dry season.

The species list (Table 4) provides preliminary information about the plants of the igapó studied. Many plants have been identified on the basis of sterile material. In the dry season many seedlings and saplings are found in open canopy areas. They have been excluded from this study because of the difficulties in identifying them. However, if their identification should become possible, their abundance can serve as an indication of the reproductive potential of the area. 


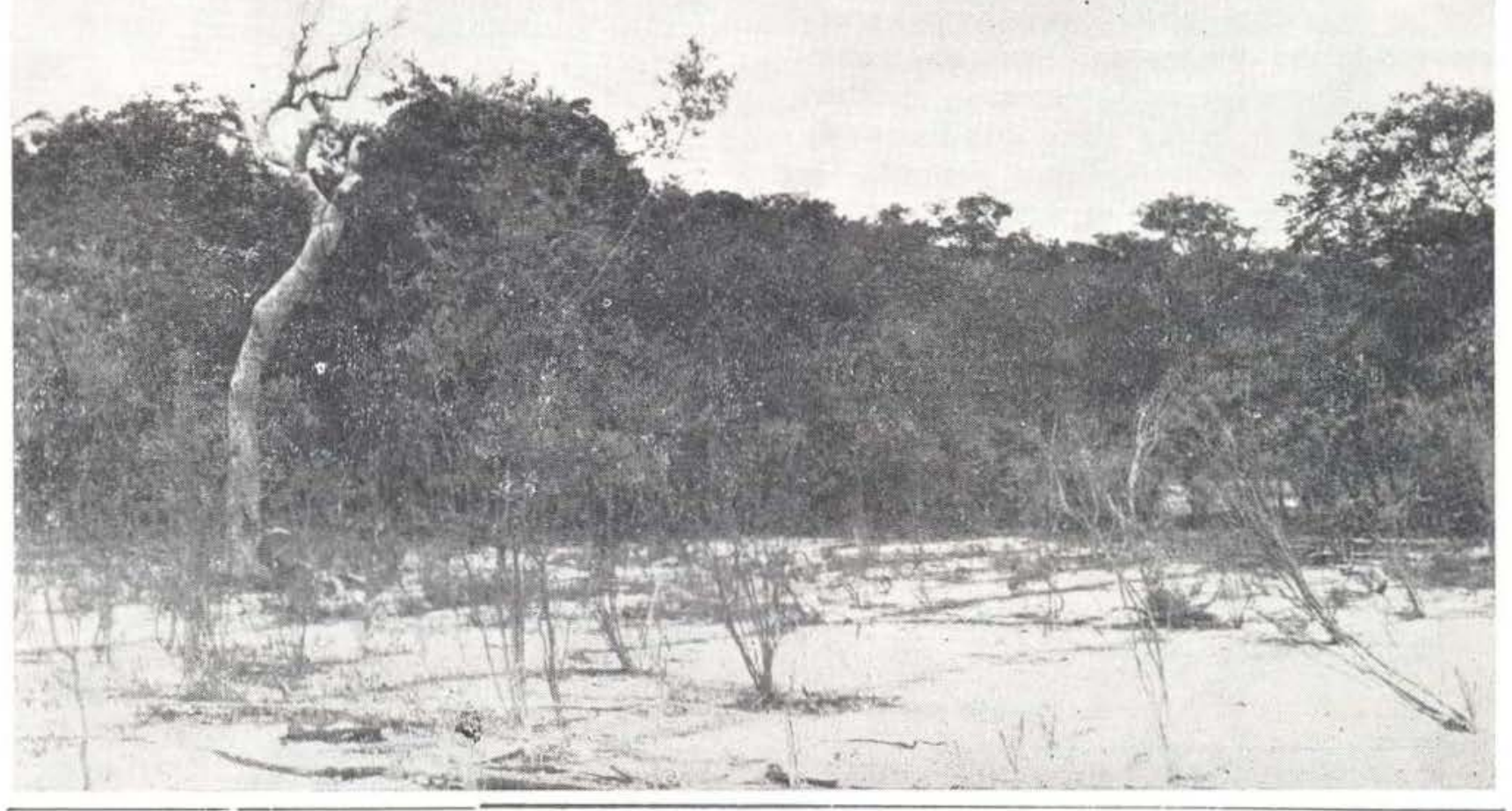

Photo 2 - Open canopy area with individual plants widely spaced and lower species diversity.

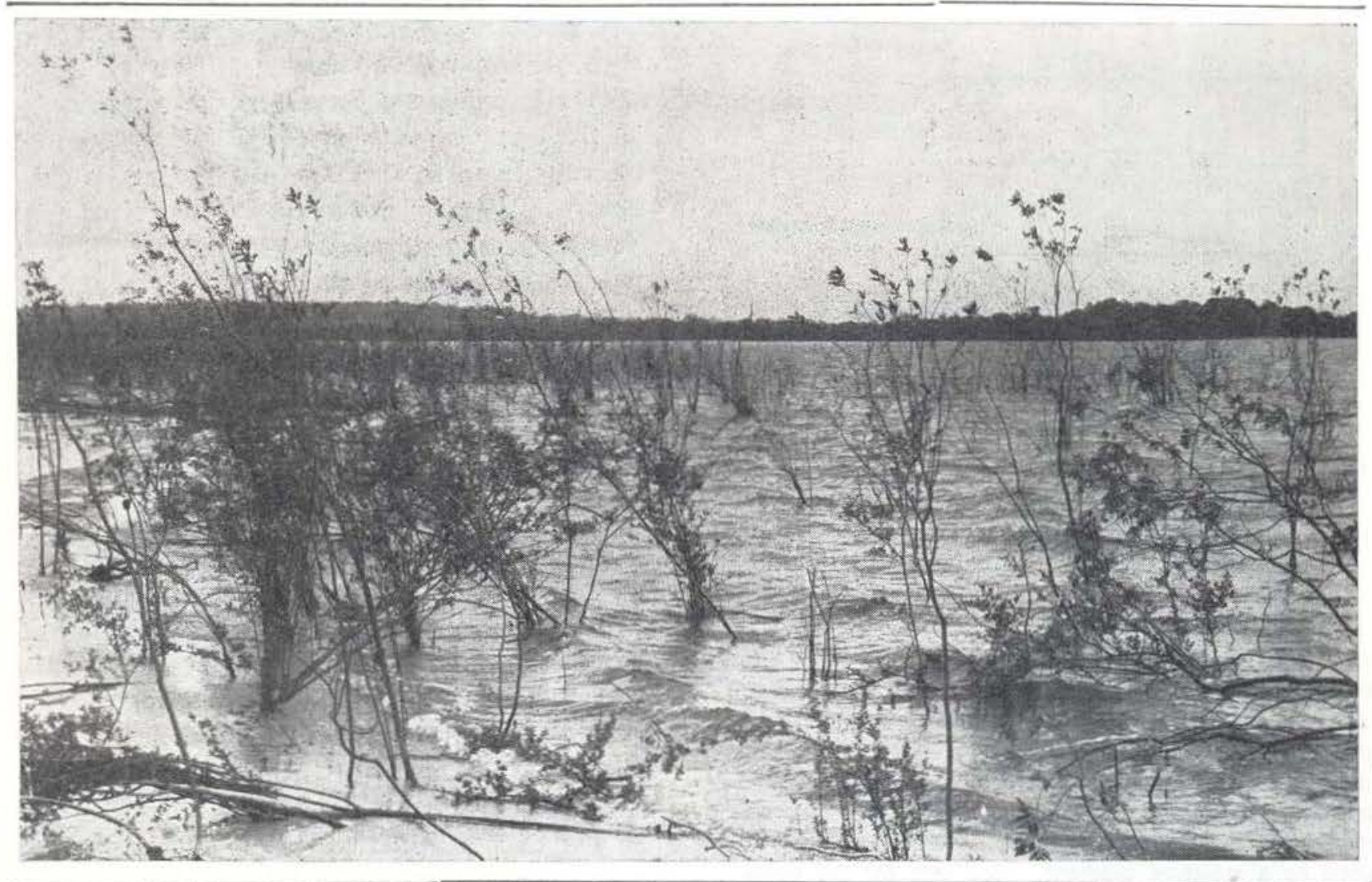

Photo 3 - Permanent water-logged area vith plants growing in the water throughout the year. 
TABLE 3. Data of vegetation analysis from 5 transects

\begin{tabular}{|c|c|c|c|c|c|}
\hline $\begin{array}{l}\text { Distance } \\
\text { from the shore }\end{array}$ & Species & $\begin{array}{l}\text { Relative } \\
\text { Frequency }\end{array}$ & $\begin{array}{l}\text { Relative } \\
\text { Density }\end{array}$ & $\begin{array}{c}\text { Relative } \\
\text { Dominance }\end{array}$ & $\begin{array}{l}\text { Importance } \\
\text { Value }\end{array}$ \\
\hline \multirow{4}{*}{$0-10 \mathrm{~m}$} & Myrciaria dubia & 50.00 & 75.00 & 99.287 & $224.287^{\circ}$ \\
\hline & Remijia tenuiflora & 16.67 & 8.333 & 0.238 & 25.241 \\
\hline & Tococa subciliata & 16.67 & 8.333 & 0.238 & 25.241 \\
\hline & Turnera acuta & 16.67 & 8.333 & 0.238 & 25.241 \\
\hline \multirow{9}{*}{$10-20 \mathrm{~m}$} & Eugenia cachoeirensis & 13.333 & 14.286 & 3.235 & 30.854 \\
\hline & E. chrysobalanoides & 20.000 & 19.048 & 2.391 & 41.439 \\
\hline & Lasiadenia rupestris & 6.667 & 4.762 & 0.013 & 11.442 \\
\hline & Leopoldinia pulchra & 6.667 & 4.762 & 0.848 & 12.277 \\
\hline & Myrciaria dubia & 13.333 & 19.048 & 49.353 & $81.734^{\circ}$ \\
\hline & Pithecellobium adiantifolium & 20.000 & 19.048 & 10.917 & $49.965^{\circ}$ \\
\hline & Schistostemon macrophyllum & 6.667 & 9.524 & 33.217 & 49.408 \\
\hline & Solanum sp. & 6.667 & 4.762 & 0.013 & 11.442 \\
\hline & Turnera acuta & 6.667 & 4.762 & 0.013 & 11.442 \\
\hline \multirow{16}{*}{$20-30 \mathrm{~m}$} & Anacampta rupicola & 9.091 & 8.571 & 1.302 & 18.964 \\
\hline & Casearia cf. commersoniana & 4.545 & 2.857 & 1.341 & 8.743 \\
\hline & Eugenia cachoeirensis & 9.091 & 8.571 & 16.754 & $34.416^{\circ}$ \\
\hline & E. chrysobalanoides & 18.182 & 34.286 & 3.688 & $56,156^{\circ}$ \\
\hline & E. cf. patrisii & 4.545 & 2.857 & 0.054 & 7.456 \\
\hline & E. cf. teffensis & 4.545 & 2.857 & 0.054 & 7.456 \\
\hline & Himatanthus attenuatus & 4.545 & 2.857 & 0.215 & 7.617 \\
\hline & Inga sp. & 4.545 & 2.857 & 2.384 & 9.786 \\
\hline & Leopoldinia pulchra & 4.545 & 5.714 & 1.469 & 11.728 \\
\hline & Myrciaria dubia & 4.545 & 5.714 & 12.633 & 22.892 \\
\hline & Ormocis excelsa & 4.545 & 2.857 & 0.006 & 7.408 \\
\hline & Pithecellobium adiantifolium & 9.091 & 8.571 & 0.053 & 17.715 \\
\hline & P. claviflorum & 4.545 & 2.857 & 0.381 & 7.783 \\
\hline & P. corymbosum & 4.545 & 2.857 & 0.024 & 7.426 \\
\hline & Proteaceae I & 4.545 & 2.857 & 0.054 & 7.456 \\
\hline & Schistostemon macrophyllum & 4.545 & 2.857 & 59.589 & $66.991^{\circ}$ \\
\hline \multirow{20}{*}{$30-40 \mathrm{~m}$} & Anacampta rupicola & 11.538 & 17.949 & 0.616 & 30.103 \\
\hline & Bactris sp. & 3.846 & 2.564 & 22.808 & 29.218 \\
\hline & Campsiandra comosa & 3.846 & 2.564 & 0.004 & 6.414 \\
\hline & Eugenia $\mathrm{cf}$, anastomosans & 3.846 & 2.564 & 0.175 & 6,585 \\
\hline & E. cachoeirensis & 15.385 & 12.821 & 63.699 & $91.905^{*}$ \\
\hline & E. chrysobalanoides & 7.692 & 12.821 & 3.656 & $24.169^{*}$ \\
\hline & E. cf. patrisii & 7.692 & 7.692 & 1.002 & 16.386 \\
\hline & E. cf. teffensis & 3.846 & 2.564 & 0.014 & 6.424 \\
\hline & Himatanthus attenuatus & 3.846 & 2.564 & 0.089 & 6.499 \\
\hline & Leguminosae II & 3.846 & 5.128 & 0.185 & 9.159 \\
\hline & Leopoldinia pulchra & 3.846 & 5.128 & 1.825 & 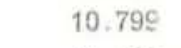 \\
\hline & Macrolobium angustifolium & 3.846 & 2.564 & 4.366 & 10.776 \\
\hline & Myrtaceae 1 & 3.846 & 2.564 & 0.014 & 6.421 \\
\hline & Pera distichophylla & 3.846 & 2.564 & 0.228 & 6.638 \\
\hline & Pithecellobium adiantifolium & 3.846 & 2.564 & 0.089 & 6.499 \\
\hline & P. claviflorum & 7.692 & 10.256 & 1.212 & 19.16 \\
\hline & Simaroubaceae II & 3.846 & 2.564 & 0.004 & 6.414 \\
\hline & Turnera acuta & 3.846 & 2.564 & 0.014 & 6.424 \\
\hline & Anacampta rupicola & 13.34 & 12.50 & 0.078 & 25.918 \\
\hline & Byrsonima sp. & 6.67 & 6.25 & 0.147 & 13.067 \\
\hline
\end{tabular}


TABLE 3 (continued)

\begin{tabular}{|c|c|c|c|c|c|}
\hline $\begin{array}{l}\text { Distance } \\
\text { from the shore }\end{array}$ & Species & $\begin{array}{l}\text { Relative } \\
\text { Frequency }\end{array}$ & $\begin{array}{l}\text { Relative } \\
\text { Donsity }\end{array}$ & $\begin{array}{l}\text { Relative } \\
\text { Dominance }\end{array}$ & $\begin{array}{l}\text { Importance } \\
\text { Value }\end{array}$ \\
\hline \multirow{11}{*}{$40-50 \mathrm{~m}^{* \bullet}$} & Eugenia cf. omissa & 6.67 & 6.25 & 2.071 & 14.991 \\
\hline & E cf. patrisii & 6.67 & 6.25 & 43.419 & $56.339^{*}$ \\
\hline & E. cf. teffensis & 6.67 & 6.25 & 0.147 & 13.067 \\
\hline & Eugenia sp. & 6.67 & 6.25 & 4.824 & 17.744 \\
\hline & Leguminosae I & 6.67 & 6.25 & 0.012 & 12.932 \\
\hline & Myrcia sp. & 6.67 & 6.25 & 0.075 & 12.995 \\
\hline & Pera distichophylla & 13.34 & 18.75 & 48.545 & $80.635^{\circ}$ \\
\hline & Pithecellobium adiantifolium & 6.67 & 6.25 & 0.003 & 12.923 \\
\hline & P. claviflorum & 6.67 & 6.25 & 0.003 & 12.923 \\
\hline & Sweetia nitens & 6.67 & 6.25 & 0.003 & 12.923 \\
\hline & Turnera acuta & 6.67 & 6.25 & 0.027 & 12.947 \\
\hline
\end{tabular}

$\because$ Data based only on 4 transects.

Species discussed in the text.

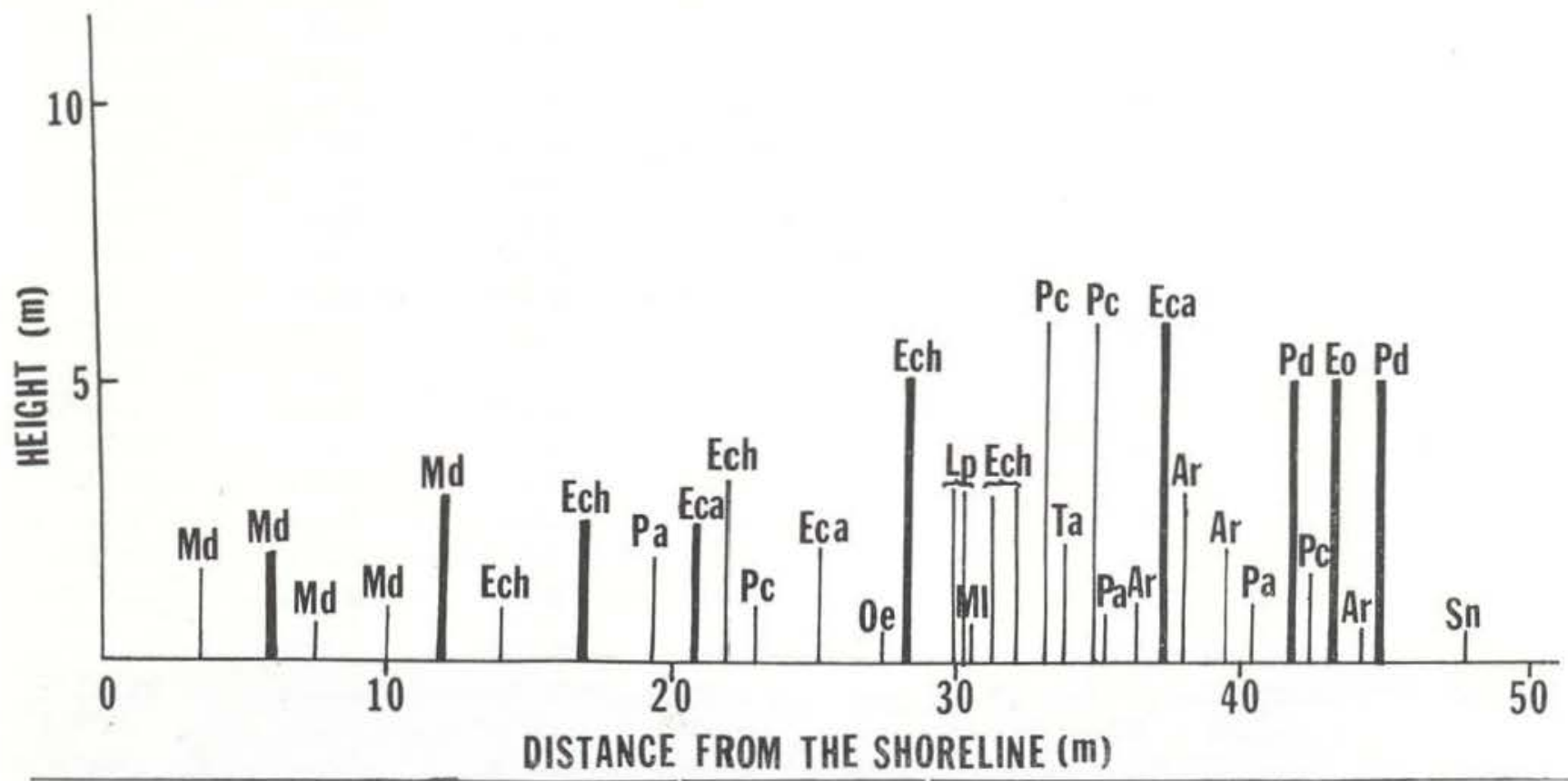

Fig. 5 - A simplified profile of a transect of $1 \times 50 \mathrm{~m}^{2}$. Thin line indicates basal diameter of stem $<10 \mathrm{~cm}$; trick line indicates basal diameter of stem $\geqq 10 \mathrm{~cm}$ but $<30 \mathrm{~cm}$; Ar: Anacampta rupicola; Eca: Eugenia cachoeirensis; Ech : E. chrysobalanoides; Eo: E. cf. omissa; Lp: Leopoldinia pulchra; Md: Myrciaria dubia; MI: Myrtaceae 1; O९: Ormosia excelsa; $\mathrm{Pa}$ : Pithecellobium adiantifolium; $\mathrm{P}_{\mathrm{c}}$ : P. claviforum; Pd: Pera distichophylla; Sn: Sweetia nitens; $\mathrm{Ta}$ : Turnera acuta.

\section{ACKNOWLEDGMENTS}

The authors wish to thank Dr. Eduardo Lleras, Director of the Botany Courses of INPA (Iristituto Nacional de Pesquisas da Amazônia, Manaus), for providing the facilities for field work. We are also grateful to Mr. José Guedes, José F. Ramos, Luís F. Coelho, and Osmarino P. Monteiro for assistance with the field work, to Dra. Marlene F. da Silva, Dr. Richard Cowan. Dr. Charles R. Gunn and Dr. Mary K. Arroyo for identifying fruit and sterile material. The authors are greatly indebted to $\mathrm{Mr}$. Peter O'Connor for his suggestions and critical review of the manuscript, and to $\mathrm{Dr}$. Maria Lebrón-Luteyn many valuable comments.

Field work was supported by NSF Grant INT75-19282, awarded to Dr. Ghillean T. Prance. 


\section{Resumo}

A vegetaçăo de um igapó de água preta na Amazônia é estudada. mostrando a dominância da espécie Myrciaria dubia (Myrtaceae) com valor de importância máxima de 75. O indice de diversidade Shannon desta vegetação foi 4.358 "bits" por individuo, de que $75.38 \%$ foi devido ao valor de igualdade. As espécies se mudam ao longo do gradiente de umidade que ocorre entre o rio e a mata ao longo dos transectos feitos. Ainda que muitas espécies tenham uma distribuição zonal, os limites não são muito bem delimitados. Esta distribuição zonal das espécies é provavelmente devido aos diferentes requerimentos de luz e diferentes tolerâncias à inundação das divorsas espécies. Uma lista completa das 54 espécies da área em estudo é apresentada, acrescida de dados sobre a freqüência, densidade, dominância e importância de cada espécie.

\section{SUMMARY}

The vegetation analysis of a Central Amazonian igapó, a forest under severe environmental stress poor soil and seasonal flooding, reveals the existence of the dominant species Myrciaria dubia with a M.I.V. 75. The Shannon diversity index of this forest is 4.358 bits per individual, of which $75.73 \%$ is attributable to the evenness value. Species distributions change along the moisture gradient. Though many species exhibit the tendency of zonal distribution, the boundaries of zones are not abrupt. The authors suggest that species distribution is the result of physiological difference to flood tolerance. Further research should be directed to the comparison of flood tolerance of the plants which occur in the foilowing three areas: permanent waterlogged area, beach area with open canopy and upper area with closed canopy. The various adaptive strategies to seasonal inundation and drought, and the reproductive potential of the forest also merit further studies.

\section{LITERATURE CITED}

Black, G.A.; Dobzhansky, T. \& Pavan, C.

1950 - Some attempts to estimate species diversity and population density of trees in Amazoznian forests. Bot. Gaz, 111:413-425.

CRAWFORD, R.M.M.

1976 - Tolerance of anoxia and the regulation of glycolysis in tree roots, pp. 387-401. In: M.G.R. Cannell \& F.T. Last (eds.). Tree Physiology and Yield Improvement. Academic Press, New York.

Drrtus, W.P.J.

1977 - The ecology of a semi-evergreen forest community in Sri Lanka. Biotropica $9(4)$ : 268-286.

DUCKE, A. \& BLACK, G.A.

1953 - Phytogeographical notes on the Bazilian Amazon. Anais Acad. Bras. Cienc. 25(1): $1-46$.
Garcín-Novo, F. \& Crawford, R.M.M.

1973 - Soil aeration, nitrate reduction and flooding tolerance in higher plants. New Phytol. 72 : 1031-1039.

KLINGE, $\mathrm{H}$, 1965 - Podzol soils in the Amazon basin. J. Soil Sci. $16: 95-103$.

MCMannon, M. \& CrAwFord, R.M.M.

1971 - A metabolic theory of flocding tolerance: the significance of enzyme distribution and behavior. New Phytol. $70: 299-306$

ODuM, H.P.

1971 - Fundamentals of Ecology. 3rd ed. W. B. Saunders Co., Philadelphia.

PIELOU, E.C.

1975 - Ecological Diversity. John Wiley \& Sons. New York.

Pires, J.M. \& Prance, G.T.

1977 - The Amazon forest: a natural heritage to be preserved. pp. 158-194. In: G.T. Prance \& T.S. Elias (eds.) Extinction is Forever. New York Bot. Gard.

PrANCE, G.T.

1979 - Notes on the vegetation of Amazonia III. The terminology of Amazonian forest types subject to inundation. Brittonia 31(1): 26-38.

PrANCE, G.T. \& ARIAS, J.R.

1975 - A study of the floral biology of Victoria amazonica (Poepp.) Sowerby (Nymphaeaceae). Acta Amazonica 5(2) : 109-139.

Scholander, P.F. \& Oliveira Perez, M.

1968 - Sap tension in flooded trees and bushes of the Amazon. Plant Physioi. 43:1870-1873.

Sioli, H.

1968 - Hydrochemistry and geology in the Brazilian Amazon region. Amazoniana 1(3): 267-277.

STARK, N.M.

1971 - Nutrient cycling I. Nutrient distribution on some Amazonian soils. Tropical Ecology $12: 24-50$.

STARK, N.M. \& Jordan, C.F.

1978 - Nutrient retention by the root mat of an Amazonian rain forest. Ecology 59(3) : 434-437.

TAKEUCHI, M

1962 - The structure of the Amazonian vegetation VI. Igapó. J. Fac. Sci. Univ. Tokyo Sect. 3 (Botany) $3: 297-304$.

TEunisSEN, P.A. 1976 - Notes on the vegetation of Suriname. Acta Amazonica $6(2): 117-150$.

WAlter, H.; HARnickell, E. \& MUeller-Dombois, D. 1975 - Climate-diagram Maps. Springer-Verlag, Berlin.

WERNSTEDT, F.L. 1972 - World Ciimate Data. Climatic Date Press.

(Aceito para publicação em 26/7/79) 